\title{
NOTE
}

\section{UNION REQUESTS FOR INFORMATION IN THE COLLECTIVE BARGAINING PROCESS}

In recent years it has become an increasingly common practice for labor unions to request a variety of information from management. These requests have been primarily for information concerning the employees in the bargaining unit represented by the union. ${ }^{1}$ In addition, unions have sought data on the employer's financial status ${ }^{2}$ and, at times, the results of management research studies. ${ }^{3}$ The justification asserted for these requests is the necessity of such information for intelligent employee representation in bargaining ${ }^{4}$ and for proper policing of the contract once negotiated. ${ }^{5}$

\section{The Development of the Bargaining Concept}

Although the practice of exchanging information is well established in some industries, ${ }^{6}$ many employers have been unwilling to comply with such union requests. Consequently, some unions have sought the aid of the National Labor Relations Board to compel disclosure, arguing that it is essential to the bargaining process. Whether bargaining requires such

1. See, e.g., NLRB v. F. W. Woolworth Co., 235 F.2d 319 (9th Cir. 1956), denying enforcement to 109 ,N.L.R.B. 196 (1954) ; Utica Observer-Dispatch v. NLRB, 229 F.2d 575 (2d Cir. 1956), enforcing 111 N.L.R.B. 58 (1955); NLRB v. Yawman \& Erbe Mfg. Co., 187 F.2d 947 (2d Cir. 1951), enforcing 89 N.L.R.B. 881 (1950); Aluminum Ore Co. v. NLRB, 131 F.2d 485 (7th Cir.), modifying and enforcing 39 N.L.R.B. 1286 (1942). See also Card, Information Requests in Collective Bargaining, 6 LAB. L.J. 777 (1955) ; Sherman, Employer's Obligation To Produce Data for Collective Bargaining, 35 MINN. L. REv. 24 (1950).

2. See Truitt Mfg. Co., 110 N.L.R.B. 856 (1954), enforcement denied, 224 F.2d 869 (4th Cir. 1955), rev'd, 351 U.S. 149 (1956); Jacobs Mfg. Co., 94 N.L.R.B. 1214 (1951), enforcement granted, 196 F.2d 680 (2d Cir. 1952); Southern Saddlery Co., 90 N.L.R.B. 1205 (1950). See also Brubaker, in What Kind of Information Do Labor Unions Want in Financial Statements?, 87 J. AccounTANCY 368 (1949); Shair, $A$ Look at the Books, 6 LAB. L.J. 53 (1955); Sherman, supra note 1.

3. Taylor Forge \& Pipe Works v. NLRB, 234 F.2d 227 (7th Cir. 1956), enfforcing 113 N.L.R.B. 693 (1955); Crompton-Highland Mills, Inc., 70 N.L.R.B. 206 (1946), enforcement denied on other grounds, 167 F.2d 662 (5th Cir. 1948), rev'd, 337 U.S. 217 (1949); see NLRB v. Otis Elevator Co., 208 F.2d 176 (2d Cir.), enforcing 102 N.L.R.B. 770 (1953).

4. E.g., Leland-Gifford Co., 95 N.L.R.B. 1306 (1951), enforcement granted on order to furnish information but rev'd on other grounds, 200 F.2d 620 (1st Cir. 1952); Electric Auto-Lite Co., 89 N.L.R.B. 1192 (1950) ; B. F. Goodrich Co., 89 N.L.R.B. 1151 (1950); see Whitin Mach. Works, 108 N.L.R.B. 1537, enforcement granted, 217 F.2d 593 (4th Cir. 1954).

5. E.g., Hearst Corp., 102 N.L.R.B. 637 (1953) ; Leland-Gifford Corp., supra note 4; B. F. Goodrich Co., supra note 4.

6. See Kirkland, in What Kind of Information Do Labor Unions Want in Financial Statements?, 87 J. AccounTancy 368, 370 (1949). 
disclosure on demand may best be considered against the background of the bargaining concept's development.

Management's assertion that a duty to comply with these requests would violate managerial prerogatives is initially predicated upon a narrow and now outdated interpretation of the National Labor Relations Act ${ }^{7}$ as reflecting no congressional intent to impose an obligation to bargain at all. Legislative history indicates that Congress' primary purpose in passing the act was to remove impediments to the organization of unions, ${ }^{8}$ and there is nothing in the act's history, or in that of the Taft-Hartley Act, ${ }^{9}$ from which it might be inferred that Congress also intended to grant the Board power to regulate the collective bargaining process or do anything more than lead the union to management's "office door." 10 Consistent with this intent, the employer unfair labor practices delimited in both labor acts relate to conduct which would hinder union organization. Only section 8 (a) (5), ${ }^{11}$ imposing on employers the duty to bargain collectively, refers specifically to the bargaining process and even this obligation is said to have been designed to prevent employers from undermining union organizational efforts, ${ }^{12}$ requiring that such bargaining as the employer chooses shall be with the union rather than directly with individual employees. Nevertheless, the statutory language does not require so limited an interpretation. While it is possible to construe the statute's enunciated policy of avoiding "industrial strife" 13 as referring only to disputes arising from efforts to organize, it is not expressly confined thereto. Furthermore, section 8(a) (5), when considered with the specification in 8(d) of subjects about which management is to confer in "good faith" 14 and concerning which 9(a) requires recognition of the union as the employees' representative, ${ }^{16}$ may be construed as imposing on the employer an affirmative duty to bargain. Accordingly, notwithstanding management's argument based on legislative history, the NLRB and the courts have interpreted the statutory language broadly to require compulsory bargaining on terms and conditions of employment. ${ }^{16}$

7. 49 STAT. 449 (1935), as amended, 29 U.S.C. \$\$ 151-66 (1946).

8. See statement of Senator Walsh in 79 CoNG. REc. 7660 (1935). infra.

9. 61 STAт. 136 (1947), as amended, 29 U.S.C. \$\$151-68 (1952); cf. note 120

10. See Cox \& Dunlop, Regulation of Collective Bargaining by the National Labor Relations Board, 63 HARV. L. REV. 389, 395 (1950).

11. 61 STAT. 140 (1947), 29 U.S.C. \& 158(a) (5) (1952).

12. Hearings Before Senate Committee on Education and Labor on S. 195, 74th Cong., 1st Sess. 79 (1935).

13. 61 STAT. 136 (1947), 29 U.S.C. § 141 (1952).

14. 61 StAT. 140 (1947), 29 U.S.C. § 158 (d) (1952).

15. 61 StaT. 143 (1947), 29 U.S.C. \& 159(a) (1952).

16. Management is at present required to bargain on such subjects as holiday and vacation pay, Singer Mfg. Co., 24 N.L.R.B. 444 (1940), modified and enforcement granted, 119 F.2d 131 (7th Cir. 1941), pensions, Inland Steel Co., 77 N.L.R.B. 1, enforcement granted, 170 F.2d 247 (7th Cir. 1948), cert. denied, 336 U.S. 960 (1949), bonuses, Union Mfg. Co., 76 N.L.R.B. 322 (1948), profit sharing, ibid., insurance benefits, W. W. Cross \& Co., 77 N.L.R.B. 1162 (1948), enforcement granted, 174 F.2d 875 (1st Cir. 1949), subcontracting, Timken Roller Bearing Co., 70 N.L.R.B. 500 (1946), 
Compulsory bargaining having been established, management maintained that discussion alone constituted "bargaining" and employers may insist on a unilateral power of decision on bargainable items without violating the act. The Board, in order to insure an element of give-and-take in the bargaining process, held that "good faith" is inherent in bargaining ${ }^{17}$ and, therefore, management's insistence on unilateral decision on bargainable subjects fails to meet the statutory requirement of "bargaining" unless such a management position is consistent with good faith. ${ }^{18}$ While the Board at first purported to examine each such case to determine whether management in fact acted in good faith, ${ }^{19}$ the view soon crystallized that insistence on unilateral decision of bargainable issues is a violation per se of the good faith standard. ${ }^{20}$ The implications for the instant problem of the Board's recognition of a per se violation will be considered later herein. ${ }^{21}$

The bargaining concept having thus evolved into an affirmative duty involving joint decision, labor further contends that good faith bargaining requires the employer upon request to furnish the union any information which the union might need for proper performance of the bargaining function. Two theories have been advanced to support this position.

One widely accepted view emphasizes the "good faith" aspect of an employer's statutory duty to bargain collectively. The "good faith" requirement, it is urged, represents an attempt by Congress to legislate a state of mind ${ }^{22}$ so that both sides will "enter into discussions with an open and fair mind and a sincere purpose to find a basis for agreement. . . ." 23 The existence of "good faith" is a question of fact to be determined by the NLRB, and an employer's refusal to comply with a union request for information may be considered evidence of an unwillingness to bargain in "good faith." Under this subjective approach, the unfair labor practice would be the employer's improper mental attitude as inferred from his refusal to furnish the information-not the refusal itself. Analytically, therefore, the good faith requirement does not create an independent obligation of disclosure, since only a particular state of mind is prescribed. Hence,

enforcement denied on other grounds, 161 F.2d 949 (6th Cir. 1947), shop rules, ibid., work schedules, Inter-City Advertising Co., 61 N.L.R.B. 1377, 1384 (1945), enforcement denied on other grounds, 154 F.2d 244 (4th Cir. 1946), rest periods, National Grinding Wheel Co., 75 N.L.R.B. 905 (1948), merit increases, NLRB v. J. H. Allison \& Co., 165 F.2d 766 (6th Cir.), cert. denied, 335 U.S. 814 (1948), enforcing 70 N.L.R.B. 377 (1946), retirement programs, Allied Mills, Inc., 82 N.I.R.B. 854 (1949) and union security, NLRB v. Andrew Jergens Co., $175 \mathrm{~F} .2 \mathrm{~d} 130$ ( 9 th Cir.), cert. denied, 338 U.S. 827 (1949), enforcing 76 N.L.R.B. 363 (1948).

17. This interpretation has been expressly incorporated into the Taft-Hartley Act's definition of collective bargaining. 61 STAT. 140 (1947), 29 U.S.C. \& 158(d) (1952); cf. note 120 infra.

18. See Aluminum Ore Co., 39 N.L.R.B. 1286, modified and enforcement granted, 131 F.2d 485 (7th Cir. 1942).

19. E.g., ibid.

20. See, e.g., J. H. Allison \& Co., 70 N.L.R.B. 377 (1946), enforcement granted, 165 F.2d 766 (6th Cir.), cert. denied, 335 U.S. 814 (1948).

21. See p. 102 infra.

22. Card, supra note 1.

23. Singer Mfg. Co., 24 N.L.R.B. 444, 464 (1940). 
the usual cease and desist remedy would not directly compel disclosure, although as a practical matter in many situations the employer would be forced to furnish some information if he is to fulfill the obligation of bargaining in "good faith." 24

A second theory advanced is that the union needs information to perform properly its statutory function as exclusive representative of the employees, and the employer should be required to furnish such information in compliance with his duty to bargain. ${ }^{25}$ It may be argued in support of this view that full disclosure of relevant information facilitates more rational and intelligent bargaining by both sides, thereby creating a greater probability of peaceable accommodation of differences. This approach would determine the employer's obligation to furnish information by the objective relevance of the requested data to the bargaining process. If the information is deemed relevant, then the union's need for it must be balanced against the possible harm that may result to the employer from its disclosure. In any event, the requirement of disclosure would not depend on the employer's mental attitude.

These two approaches seem to represent conflicting views as to how the collective bargaining process should operate. If all that is necessary is for management and labor to sit down together and discuss their differences with a mutual desire to reach agreement, then the subjective requirement of "good faith" provides a sufficient standard for the obligation to furnish information. ${ }^{28}$ By this approach, refusal to furnish requested information would be an unfair labor practice only where it indicated that the employer lacked an "open and fair mind." On the other hand, collective bargaining can be considered not as an end in itself but rather as a means of accomplishing the broader statutory purpose of avoiding strikes and other forms of industrial strife, imposing such reasonable requirements as may contribute to management-labor rapprochement. ${ }^{27}$ Under this interpretation, an objective ascertainment of the information needed to create conditions conductive to agreement would be the appropriate method for determining what data the employer must make available to the union.

The Board has utilized both approaches in cases which have come before it. ${ }^{28}$ Moreover, both have formed the basis for orders requiring the disclosure of information. ${ }^{29}$ Regardless of the theory advanced, how-

24. See Aluminum Ore Co., 39 N.L.R.B. 1286, modified and enforcentent granted, 131 F.2d 485 (7th Cir. 1942), where the lack of the requested information made it impossible for the union to understand the employer's wage structure, thus effectively preventing the union from bargaining on wages.

25. See Whitin Mach. Works, 108 N.L.R.B. 1537, enforcement granted, 217 F.2d 593 (4th Cir. 1954).

26. Cf. Cox \& Dunlop, supra note 10.

27. Cf. NLRB v. Truitt Mfg. Co., 351 U.S. 149, 152 (1956).

28. See, e.g., Whitin Mach. Works, 108 N.L.R.B. 1537, enforcement granted, 217 F.2d 593 (4th Cir. 1954) (objective approach) and Southern Saddlery Co., 90 N.L.R.B. 1205 (1950) (subjective approach).

29. Compare New Britain Mach. Co., 105 N.L.R.B. 646 (1953), enforcement granted, 210 F.2d 61 (2d Cir. 1954) (objective approach), with Jacobs Mfg. Co., 94 N.L.R.B. 1214 (1951), enforcement granted, 196 F.2d 680 (2d Cir. 1952) (subjective approach). 
ever, employers have objected to orders requiring disclosure as an invasion of their "managerial prerogatives." 30 This claim of "managerial prerogative" premises that ownership of a business carries with it certain rights which may not be restricted, and that among these is the right to withhold information about that business. ${ }^{31}$ Based as it is on an assertion of the rights of private property, this argument has strong emotional appeal to many. Nevertheless, management's claim that it need not furnish information merely because it so prefers cannot be persuasive where disclosure may be essential to accomplish a statutory objective.

Since the issues must vary somewhat with the data requested, an employer's duty to furnish requested information will be examined herein according to the three major types of information involved: that concerning the employees, the employer's financial status and management research studies. Thereafter, some consideration will be given to questions arising when it is claimed that the union has waived its right to obtain information or that the subsequent conclusion of a contract has eliminated any obligation of disclosure.

\section{Information Relating to EmployeEs}

Much of the data sought by unions pertains to pay rates, ${ }^{32}$ hours worked, ${ }^{33}$ job classification ${ }^{34}$ and seniority status ${ }^{35}$ of the employees in the bargaining unit. Although most of this information could be supplied by the employees, it is more convenient, cheaper and less time-consuming for the union to obtain it directly from the employer. ${ }^{36}$ In addition, where the bargaining unit is large, it may be impractical for the union to poll all the employees. ${ }^{37}$ Moreover, by having the employer furnish the information, errors arising in its compilation as well as those resulting from the tendency of employees to exaggerate their positions are eliminated. ${ }^{38}$ Finally, this

30. Sherman, supra note 1. (1956).

31. Cf. Lipstreu, Management Rights: Conflict or Cooperation?, 7 LAB. L.J. 555

32. See, e.g., NLRB v. Whitin Mach. Works, 217 F.2d 593 (4th Cir.), enforcing 108 N.L.R.B. 1537 (1954); NLRB v. Yawman \& Erbe Mfg. Co., 187 F.2d 947 (2d Cir. 1951), enforcing 89 N.L.R.B. 881 (1950) ; Aluminum Ore Co. v. NLRB, 131 F.2d 485 (7th Cir.), modifying and enforcing 39 N.L.R.B. 1286 (1942).

33. See F. W. Woolworth Co., 109 N.L.R.B. 196 (1954), enforcement denied, 235 F.2d 319 (9th Cir. 1956).

34. See cases cited in note 32 supra.

35. See NLRB v. Whitin Mach. Works, 217 F.2d 593 (4th Cir.), enforcing 108 N.L.R.B. 1537 (1954).

36. If furnishing the information necessitates any unreasonable expenditures, it would seem reasonable to require the union to reimburse the employer. See Whitin Mach. Works, 108 N.L.R.B. 1537, 1541 (1954) (concurring opinion); cf. text at note 91 infra.

37. Cf. Aluminum Ore Co., 39 N.L.R.B. 1286, modified and enforcement granted, 131 F.2d 485 (7th Cir. 1942) (request for information concerning employees no longer working for the company).

38. Westinghouse Elec. Corp., 113 N.L.R.B. 954, 977 (1955); Electric Auto-Lite Co., 89 N.L.R.B. 1192, 1199 (1950). 
procedure avoids possible friction between the union ${ }^{39}$ and any non-union members of the bargaining unit represented by the union.

Management has been unenthusiastic about supplying this information. Not only does management gain no direct advantage from relieving the union of the burden of gathering such data for itself, but employers generally are not anxious to assist in improving union bargaining ability. However, the extent of this resistance no doubt varies with the amount of effort the employer must expend in furnishing the data, the benefit that might accrue indirectly through cordial relations with the union and the willingness of the particular employer to accept the increased power and prestige of the union.

The first case in which an employer's failure to furnish wage information was held a refusal to bargain in good faith was Aluminum Ore Co. ${ }^{40}$ Prior to 1941 it had been the practice of the company, with union acquiescence, to set wages unilaterally. ${ }^{41}$ In 1941, when the union sought to obtain a wage increase for all employees, the company took the position that negotiation of wages on an over-all basis was against its policy and it would discuss wages only on an individual basis. The company then refused to supply the union with job classification data, rendering the union unable to understand the company's wage structure, and, in an attempt to escape negotiation on a general basis, unilaterally granted most employees a wage increase. The Board held that the company had refused to bargain collectively, and issued a cease and desist order. However, the company was not ordered to furnish the requested information, which indicates that the Board viewed the failure to supply the information not as itself constituting bad faith but only as evidence thereof.

Subsequent decisions also treated an employer's refusal to furnish data as merely evidence of bad faith, but in each such case there was always other employer conduct to corroborate a bad-faith finding. ${ }^{42}$ Finally, in Yawman \& Erbe Mfg. Co.," the impracticability of the "evidence" approach was exposed: with other evidence lacking, the only conduct alleged to establish bad faith was the company's refusal to furnish wage data.

The dispute in Yareman \& Erbe arose when, in response to the union's demand for an increased minimum wage, the company offered to renew the existing contract. At this point the union requested a list of the employees and their wage rates under the current contract and those of the two prior years. The employer, contending that this information was not

39. See F. W. Woolworth Co., 109 N.I.R.B. 196, 205 (1954). 1942).

40. 39 N.L.R.B. 1286, modified and enforcement granted, 131 F.2d 485 (7th Cir.

41. Id. at 1290.

42. See Vanette Hosiery Mills, 80 N.L.R.B. 1116 (1948); National Grinding Wheel, 75 N.L.R.B. 905 (1948); J. H. Allison \& Co., 70 N.L.R.B. 377 (1946), enforcement granted, 165 F.2d 766 (6th Cir.), cert. denied, 335 U.S. 814 (1948); Sherwin-Williams Co., 34 N.L.R.B. 651 (1941), enforcement granted, 130 F.2d 255 (3d Cir. 1942).

43. 89 N.L.R.B. 881 (1950). 
necessary to bargain on minimum wages, refused to comply. The NLRB found the current data relevant to the negotiations because of management's offer to renew the existing contract and because the going rate, in any event, is a factor to be considered by a union when deciding to press for a wage increase. Failure to furnish wage data under the existing contract was deemed an unfair labor practice, and the employer was ordered to supply it. The order did not extend to the earlier data, however, for the Board held this had not been shown relevant. Board member Murdock dissented as to the information for prior years, asserting that no specific finding of relevancy should be required since "this is one of those areas where the specific need for information may not be apparent until it has been made available." 44 In enforcing the Board's order, the Court of Appeals for the Second Circuit said that an employer has ". . . an affirmative statutory duty to supply relevant wage data . . ." and that ". . . the information must be disclosed unless it plainly appears irrelevant." 45

\section{The Issue of Relevance}

Yareman \& Erbe marked a change in the NLRB's approach to the wage information problem. Significantly lacking in that decision was an attempt to evaluate the employer's "good faith" mental attitude; instead the Board focused on the information's relevance to collective bargaining.

The developing relevance approach was climaxed in Whitin Mach. Works.48 There the employer had given employees' names, job classifications, seniority status and wage rates to the union, but refused to link the wage rates to individuals, contending such specificity was unnecessary because the union sought only a general wage increase. In citing this refusal as an unfair labor practice, the NLRB based the union's right to such knowledge on its status as exclusive employee representative under section 9(a). Since wage data is at the core of bargaining and administration of employment contracts, the Board viewed its denial as tending to undermine the union's standing, and the employer was placed under an affirmative duty to supply such data without a demonstration of its specific relevance.

Whitin's "presumption" of relevance, while inferentially supported by the majority, was articulated only in Chairman Farmer's concurring opinion where he indicated that, in future cases of this kind, he would consider employers obligated to furnish such data as is generally material to the entire collective bargaining process, without examining its relevance to the particular bargaining issues, unless the employer establishes that the request was made for purposes of harassment and, hence, not in good faith. ${ }^{47}$ This broad rule was regarded necessary to arrest the bickering and

44. $I d$. at 885 .

45. NLRB v. Yawman \& Erbe Mfg. Co., 187 F.2d 947, 949 (2d Cir. 1951).

46. 108 N.L.R.B. 1537, enforcement granted, 217 F.2d 593 (4th Cir. 1954).

47. Id. at 1541 . 
jockeying that had characterized employer reaction to union demands for such information.

Shortly thereafter, in Boston Herald-Traveler Corp., ${ }^{48}$ this view was adopted by the entire Board and expressly affirmed by the First Circuit in enforcing the Board's order. ${ }^{49}$ The court found the rule desirable because of the virtual impossibility of predicting the course of negotiations and, therefore, the need for given data. Since disclosure might reveal wage inequities which might then become the subject of bargaining, only where the information is patently outside bargaining areas can it realistically be considered irrelevant.

Judicial approval of this theory has not been unanimous, however. Recently the Ninth Circuit, in NLRB v. F.W.Woolvorth Co., ${ }^{50}$ refused to enforce a Board order to furnish wage data. The court, although recognizing that in some circumstances an employer has a statutory duty to provide wage information, opined that such information is "highly confidential" to the employee and, therefore, should be disclosed only when the union demonstrates a specific need for it. The problem was conceived as one of balancing the employee's right of privacy against the union's need for the information. The advisability of allowing an employer to raise employees' privacy as a defense, though, is questionable. ${ }^{.1}$

On the whole, the presumptive relevancy approach seems a rational solution. For wage bargaining the union must have a list of all employees in the unit together with their seniority status, job classifications and pay rates in order to decide intelligently whether to negotiate on minimum wage rates, across-the-board increases, merit increases or alternative plans. In addition, this data is necessary if the union is to detect discriminatory practices. ${ }^{52}$ Without such facts the union would be unable to fulfill its statutory responsibility of representing all employees in the bargaining unit. Furthermore, as pointed out in the Herald-Traveler case, a specific demonstration of relevancy may be impossible because of the difficulty of foretelling what information will be needed for the bargaining; if the information is to be of any use to the union, it must be available sufficiently in advance of negotiations for the union to study it. At the same time, furnishing this information will seldom, if ever, hurt the employer. Primarily it is a question of the employer providing the information or the union undertaking a burdensome and often unfeasible survey of the employees. Finally, this broad rule has the advantage of reasonable definiteness and thus will tend to eliminate much of the quibbling as to which information should be supplied.

48. 110 N.L.R.B. 2097 (1954).

49. Boston Herald-Traveler Corp. v. NLRB, 223 F.2d 58 (1st Cir. 1955).

50. 235 F.2d 319 (9th Cir. 1956), denying enforcement to 109 N.L.R.B. 196 (1954).

51. See pp. 98-99 infra.

52. See Boston Herald-Traveler Corp., 110 N.L.R.B. 2097 (1954), enforcement granted, 223 F.2d 58 (1st Cir. 1955). 


\section{The Defense of Confidentiality}

Employers have in several cases contended they should not be compelled to furnish wage data because it is confidential to themselves or their employees. Of this defense in Aluminum Ore Co. v. NLRB ${ }^{53}$ the court observed:

"We can conceive of no justification for a claim that such information is confidential. Rather it seems to go to the very root of the facts upon which the merits were to be resolved. . . . And if there be any reasonable basis for the contention that this may have been confidential data of the employer before the passage of the Act, it seems to us it can not be so held in the face of the expressed social and economic purposes of the statute." 54

It therefore seems clear that an employer's claim that these records are confidential will be rejected, at least without some demonstration that disclosure will result in injury to a legitimate business interest. In only two cases has such an injury been asserted, and in both the argument was rejected. In Post Publishing $C{ }^{.55}$ the employer's claim that disclosure of wage data would create jealousy among employees and have a harmful effect on their morale was dismissed as "too speculative." 56 Later, in Boston Herald-Traveler Corp., the employer contended that such disclosure would lead to the pirating of some of his employees by competing newspapers. The Board found this danger outweighed by the value of informed bargaining.

These cases may not preclude an employer's defense of injury to his business from disclosure, but there seem few conceivable situations where disclosure would be sufficiently detrimental to necessitate withholding the data from the union. This type of information is not wholly secret; the employees, if they wished, could reveal it themselves.

A more difficult question arises where the employer claims that disclosure would be an invasion of his employees' privacy. Undoubtedly many employees would not want their salaries disclosed, and some courts and members of the Board have been sensitive to this desire for privacy. Two recent circuit court decisions are illustrative of the conflicting views on this question. In Utica Observer-Dispatch v. NLRB ${ }^{57}$ the company informed each employee that it would furnish wage data to the union unless the employee objected. In holding that the information must be supplied notwithstanding employee objection, the Second Circuit upheld the Board's theory that disclosure is not contingent on employee consent since the union

53. 131 F.2d 485 (7th Cir.), modifying and enforcing 39 N.L.R.B. 1286 (1942).

54. Id. at 487 .

55. 102 N.I.R.B. 648 (1953).

56. It should be noted that any unfair wage differentials such as would create employee jealousy are of legitimate concern to the union.

57. 229 F.2d 575 (2d Cir. 1956), enforcing 111 N.L.R.B. 58 (1955). 
has a statutory right to this information arising from its duty to represent the employees. ${ }^{58}$ On the other hand, in denying enforcement of a Board order to furnish wage data, the Ninth Circuit in NLRB v. F.W.Woolworth Co. said that there were "a number of cogent arguments that the employee should have a right of privacy on payroll information" 59 and that, before it would enforce disclosure of information "highly personal to employees," 60 there must be some demonstration of the data's specific relevance to the negotiations.

While the Woolworth Company's concern for the privacy of its employees may be praiseworthy, there is something incongruous about an employer protecting his employees from their own union. Perhaps the better solution is that suggested in NLRB v. Item Co., ${ }^{81}$ where the court concluded it would be unwise to let employers rely on employee rights because such defenses would disturb orderly bargaining procedure and tend to undermine union authority. ${ }^{62}$

\section{Disciosure of Financial Information}

For several years labor leaders have expressed their interest in information on the employer's financial status. ${ }^{03}$ Such information enables a union to evaluate the effect on the employer of proposed wage increases ${ }^{64}$ and other employee benefits. Moreover, where the employer's ability to pay a wage increase is injected into the negotiations, the union is unable to discuss the matter intelligently without access to the information on which the employer relies. ${ }^{65}$ At the same time, such information enables the union to assess the employer's financial strength and to determine his ability to withstand a strike, thereby improving the union's strategic position in the negotiations.

Management generally has been unwilling to make available data concerning its financial position. Much of this resistance can be attributed to a feeling that such information is private. ${ }^{66}$ Employers have also voiced the fear that a consequence of such divulgence will be dispute over pricing and accounting policies-matters which they consider within the realm of

58. Moreover, the court affirmed the Board's holding that, in informing the employees of the union's request and giving them the opportunity to object to it, the company had committed an unfair labor practice because such direct dealing with the employees tended to cripple the union's prestige.

59. 235 F.2d at 321 .

60. Id. at 323 .

61. 220 F.2d 956 (5th Cir. 1955), cert. denied, 25 U.S.L. WEEK 3153 (U.S. Nov. 19, 1956) (No. 450), enforcing 108 N.I.R.B. 1634 (1954); see also Utica ObserverDispatch v. NLRB, 229 F.2d 575 (2d Cir. 1956), enforcing 111 N.L.R.B. 58 (1955).

62. The court quoted Justice Frankfurter in Brooks v. NLRB, 348 U.S. 96, 103 (1954): "The underlying purpose of the statute is industrial peace. To allow employers to rely on employees' rights in refusing to bargain with the formally designated union is not conducive to that end, it is inimical to it."

63. See Sherman, supra note 1. For the type of data requested, see id. at 26-27.

64. See Kirkland, supra note 6.

65. See Southern Saddlery Co., 90 N.L.R.B. 1205 (1950).

66. See Daykin, Furnishing Wage Data for Bargaining, 4 LAB. L.J. 417 (1953). 
managerial prerogative. ${ }^{67}$ Finally, it is contended that disclosure of such data could aid competitors to the disadvantage of the disclosing company. ${ }^{68}$

The leading NLRB decision on the employer's duty to impart financial information is Southern Saddlery Co., ${ }^{69}$ where the company refused to grant a wage increase on the ground that it was financially unable to do so. When the union requested information substantiating the claim of financial inability, the company declined, asserting that divulgence of such information to anyone was contrary to its policy. The Board rejected this argument, declaring:

"The Respondent, by maintaining the intransigent position that it was financially unable to raise wages and, at the same time, by refusing to make any reasonable efforts to support or justify its position, erected an insurmountable barrier to successful conclusion of the bargaining. We believe that such conduct does not meet the test of good faith bargaining." 70

Although the Board ordered Southern Saddlery to bargain in good faith, without specifically requiring production of any information, as a practical matter the company was forced to substantiate its claim. In a similar case the following year, the employer was specifically ordered to furnish "such statistical and other information as will substantiate the Respondent's position in bargaining. . . ." 71 The Board has never held, however, that an employer must allow the union to examine his books. His obligation is said to be that of explaining the reasons for his position and supplying enough information to enable the union to bargain intelligently on the issues involved. ${ }^{72}$

Recently, the Supreme Court in $N L R B$ v. Truitt $M f g$. Co $^{73}$ unanimously agreed that refusal to substantiate a claim of inability to pay increased wages was evidence that the employer was bargaining in bad faith. Moreover, a majority of the Court ${ }^{74}$ felt that this evidence alone was sufficient to support a finding of bad faith. The Court, however, expressly limited its holding to the facts of the case. Three dissenting Justices ${ }^{75}$ maintained that proper application of the good faith standard requires consideration of the totality of the employer's conduct, and urged the case's remand to the Board for receipt of other evidence as to the employer's attitude.

67. See Sherman, supra note 1 , at 34 .

68. Id. at 35 ; see also Daykin stipra note 66 .

69. 90 N.L.R.B. 1205 (1950).

70. Id. at 1207 .

71. Jacobs Mfg. Co., 94 N.L.R.B. 1214, 1226 (1951), enforcement granted, 196 F.2d 680 (2d Cir. 1952).

72. McLean-Arkansas Lumber Co., 109 N.L.R.B. 1022, 1023, 1037 (1954).

73. 351 U.S. 149 (1956); cf. NLRB v. I.B.S. Mfg. Co., 210 F.2d 634 (5th Cir. 1954), denying enforcenent to 96 N.L.R.B. 1263 (1951).

74. Chief Justice Warren, Justices Black, Reed, Douglas, Burton and Minton.

75. Justices Frankfurter, Clark and Harlan. 
Although the Court purported to follow the subjective "good faith" approach, its approval of the NLRB's bad-faith finding merely from the failure to furnish information seems inconsistent therewith. The tacit inference that an unsubstantiated claim is a dishonest claim is certainly permissible, but the employer's refusal to furnish financial information may as rationally be attributed to other, less reprehensible motivations such as a justifiable belief that the data will fall into the hands of competitors who will use it to his detriment ${ }^{76}$ or simply that there was no obligation to produce the data. ${ }^{77}$ If the subjective approach is to be retained the Truitt dissenters' view logically follows, for an employer's refusal to disclose is only one factor which should be weighed together with his other conduct in order to determine his willingness to cooperate with the union. Only where the requested data is needed by the union for a valid purpose would his refusal even tend to indicate bad faith. However, by this view should the employer's other conduct indicate a cooperative attitude he may well not be adjudged to have refused to bargain, in which case the union would still lack data essential to effective bargaining. At the same time, if the employer's general conduct indicates an unwillingness to bargain, although the refusal by itself is based on protection of a legitimate business interest, the inquiry into this defense would be prejudiced and confused by the evidentiary impact of his other conduct. The subjective approach therefore seems inadequate. It permits results which, on the one hand, may frustrate the objectives of collective bargaining and, on the other hand, may impede consideration of the genuine interests involved. It appears more realistic and constructive to make the inquiry on an objective basis with the dispositive order requiring or denying access to the requested information. If there is authentic need for the data, failure to produce it should constitute bad faith except when divulgence will result in damage to the employer disproportionate to the information's value to the union.

Whenever information dealing with the employer's financial condition is relevant to an issue about which the parties are bargaining, its need to the union is obvious. Such data becomes relevant when management and the union stipulate that the employer's ability to pay is a proper factor to be considered in bargaining on a given issue as well as when the employer has pleaded economic inability and the union has agreed to consider this. Although knowledge of the employer's position may aid the union in planning its bargaining tactics, there appears to be no authority for recognizing this use as one related to bargaining, since the bargaining process, even to the extent that it is regulated, has not been wholly removed from arm's length dealing. Therefore, since information relating to the merits of the employer's financial condition will not logically tend to move the

76. In Truitt there was no contention that disclosure would be injurious to the company's business. It was perhaps the implications of such a contention in a future case that led the Court to limit the Truitt holding to its facts, 351 U.S. at 153-54, although the Court gave no indication of what facts might give rise to a different decision.

77. See Truitt Mfg. Co., 110 N.L.R.B. 856, 861 (1954). 
parties closer to final agreement until the parties stipulate that the data should be considered in arriving at a settlement, it is submitted that only then should the data be deemed relevant. Once need has been demonstrated, the only factor militating against disclosure is the possibility that the employer may be injured thereby.

On the issue of injury the usual claim is that competitors and the union may use the disclosed data to management's detriment. It is doubtful whether much of the disclosed material could be of any real aid to competitors. ${ }^{78}$ However, to provide against such contingency management could condition divulgence on the union's agreement to indemnify the employer for injury resulting from any violation of the confidential relationship from which need for the data arose. ${ }^{79}$ Fear of the union's use of the information for strategic purposes-i.e., determining the company's ability to withstand a strike-may have some basis, but it is not a practical problem since such calculations usually are not accurate or even possible. ${ }^{80}$ It should be of concern only to employers who are unable to afford the proposed increase and also have an obviously weak financial position, and for them it is probably worth risking the injury in order to demonstrate to the union the company's inability to pay the increase. Where the employer is financially strong, although the union may find this fact helpful in planning its bargaining tactics the disclosure may redound to the employer's benefit by persuading the union that it would be foolhardy to strike. Therefore, it is submitted that since the possible injury from disclosure will not outweigh the value of the data to the union where such is relevant, a refusal to furnish it despite union indemnification for a breach of confidence should be a per se violation. The Truitt majority approximates this view, disclaimers notwithstanding, and adequate precedent for a per se doctrine may be found in the cases on an employer's reservation of unilateral power of decision ${ }^{81}$ and in the presumptive relevance of wage data. ${ }^{82}$

Positing a requirement to disclose where the employer's ability to pay is an issue, when should the information be made available? At present the union is not entitled to the information until the employer claims eco-

78. Information concerning the general financial status of many companies is already available to the public in the form of published financial statements. In addition, information about companies that do not publicly disclose their financial standing can be obtained through Dun \& Bradstreet reports. Of course there may be some bargaining situations in which it will be necessary for the employer to disclose detailed cost information which would not otherwise be available to the public. However, this will not be the typical situation. See Sherman, supra note 1 , at 35 .

79. Although the effectiveness of this remedy may be limited by the difficulties involved in establishing the violation and the extent of damage resulting to the employer, it would still seem preferable to the alternative of permitting the lack of necessary information to block a successful conclusion of the negotiations.

80. Financial strength is only one of the factors determining how long an employer will resist union demands. Another factor is the extent to which financial aid will be forthcoming from other sources, such as suppliers or customers, to support the fight against the union. In addition, an important consideration will be the extent to which the employer believes he can pass the wage increase along to his customers in the form of higher prices.

81. See p. 92 supra and cases cited in note 16 supra.

82. See pp. 96-97 supra. 
nomic inability. ${ }^{83}$ Ordinarily this occurs in the midst of negotiations so that even if the data is supplied there is little time for the union representatives to study it. It would thus seem desirable that the data be forthcoming prior to negotiations. However, the material will never be needed unless the employer's ability to pay becomes an issue in the negotiations. In view of the potential harm to the employer it appears improper to require disclosure on the mere possibility that the information may be needed. One solution would be for the union to request the material in advance of the principal bargaining sessions. The employer could then either comply with the union request or declare that his ability to pay is not relevant. In the latter instance the union may still consider the employer's ability to pay relevant in determining the wage scale, but the employer's financial status will not itself become an issue in negotiations if management has agreed not to challenge labor's proposal on this basis. In the event that the employer later unexpectedly injects a claim of economic inability it would seem proper to cite his earlier refusal as an unfair labor practice.

\section{Management Research Data}

Management's wage policies are often founded on information supplied by time studies and other research techniques. ${ }^{84}$ Data so produced may underlie a company's determination of its bargaining offer as well as the maximum it is willing to pay in order to avert a strike. This information also may be used in setting prices, scheduling plant activity and realizing production efficiencies, and would therefore be extremely harmful in the hands of competitors. Potential harm from this source and the possibility that union leaders will contest the data's accuracy or reliability - subjects which management considers within its own province-make employers reluctant to reveal such studies to the union.

\section{Time Studies}

Union requests for a copy of management's time study, or for permission to make its own, typically occur when the parties are considering linking wages to the worker's productivity as measured by time. A characteristic incentive system involves assignment of a point rating for each job operation. Theoretically a point is the equivalent of one minute's work. However, the work to be assigned a point is calculated so that the average employee can do more than sixty points of work an hour, and bonuses are awarded for the excess hourly points. Under this type of plan, the points per operation would be assigned either pursuant to agreement between the parties ${ }^{85}$ or by management alone subject to review in a

83. See NLRB Ad. Rul., Case No. K-467, 38 L.R.R.M. 1076 (May 17, 1956); NLRB General Counsel Rul., Case No. 951, 34 L.R.R.M. 1208 (1954).

84. For a brief discussion of the application of time studies to various systems of wage payment, see MERRICK, TIME STUdIES AS A BASIS FOR RATE SETring 333-54 (1920).

85. Crompton-Highland Mills, Inc., 70 N.L.R.B. 206 (1946), enforcement denied on other grounds, 167 F.2d 662 (5th Cir. 1948), rev'd, 337 U.S. 217 (1949). 
grievance proceeding instituted by the union. ${ }^{88}$ In either case, if the parties were to bargain merely on the basis of estimates, with no time study having been made, there would seem no statutory basis for requiring the employer to permit a union-sponsored time study just because the NLRB may consider such a study a more accurate basis for negotiations. However, if the employer is bargaining with the knowledge of an existing time study, not only is the time-study data made relevant to the issue of wage setting but the union is then unable to negotiate intelligently without access to similar information. In this situation, then, the conclusion seems justified that a refusal to make such information available manifests bad faith, notwithstanding an otherwise general willingness to cooperate. The union could acquire the necessary information either by conducting its own time study, if given permission to enter the plant, or by obtaining a copy of management's study.

The first case testing a union's right to a copy of management's time study was Crompton-Highland Mills, Inc. ${ }^{87}$ In the course of negotiating wages under an incentive plan, the union requested a copy of the company's time study. The company refused, but offered to let the union make its own study. The NLRB held that, in view of this offer, the employer's refusal did not show bad faith. One member dissented, contending that the delay resulting if the union has to conduct its own study would be such as to make this alternative unreasonable and, therefore, such an offer did not excuse the company from supplying the data.

Subsequently, in Otis Elevator Co., ${ }^{88}$ where the company rejected union demands for an opportunity to conduct a union-sponsored time study and for a copy of management's study as well, the Board held the company to have refused to bargain and ordered it to comply with both requests. However, the Second Circuit denied enforcement to that part of the order requiring the employer to let the union make its own time study, ${ }^{89}$ reasoning that the union could acquire sufficient information from examining the employer's study and discussing it with the employees involved. Judge Clark urged in dissent that if the union is to be allowed some information it should not be stopped short of acquiring the most useful data it could develop.

Although these cases were purportedly decided on the basis of whether the employer's refusal indicated a lack of good faith in bargaining, their import seems wider. In each case there was no other evidence of an unwillingness to bargain; in fact, the employer was, at the time of his refusal, negotiating with the union on the job standards involved. As a result, these cases can be considered as establishing that whenever management

86. Otis Elevator Co., 102 N.L.R.B. 770, enforcement granted, 208 F.2d 176 (2d Cir. 1953).

87. 70 N.L.R.B. 206 (1946), enforcement denied on other grounds, 167 F.2d 662 (5th Cir. 1948), rev'd, 337 U.S. 217 (1949).

88. 102 N.L.R.B. 770 (1953).

89. NLRB v. Otis Elevator Co., 208 F.2d 176 (2d Cir. 1953). 
resorts to a time study in the course of bargaining the union is also entitled to such data.

Even so, the employer apparently has a choice between revealing the company study to the union or allowing the union itself to conduct a study. From the union's standpoint, these alternatives will not always be equally desirable. For instance, where the union doubts the accuracy of the employer's time study, it will prefer making its own. ${ }^{90}$ If a union study can be completed without unreasonably interfering with plant operation there would appear no reason for denying the union request. On the other hand, where the nature or extent of operations makes a time study very costly, the union may be satisfied with a copy of the employer's study. However, in this situation it seems reasonable to condition the employer's obligation to furnish his study on the union's willingness to share the cost.91

\section{Job Evaluation}

Another technique employed in setting wages is job analysis in terms of a point rating for each of several designated factors according to their relative significance in the particular job. For example, one such factor is the task's "physical demand," for which a rating manual specifies point allocations in five degrees varying from "light work requiring little physical effort" to "continuous physical exertion working with heavy weight material." 92 The total points given to all factors is the job rating on which is based the wage rate assigned to the job.

Where such a system is employed, it is crucial in bargaining on wage rates that the union know the job description and job rating for all employees in the unit. Moreover, in order to discuss each job rating intelligently the union would need a copy of the rating manual which specifies the points to be assigned for each degree of the designated factors. In addition, some unions have requested for each job the individual point ratings according to management's evaluation of each factor. The NLRB, in Taylor Forge $\mathcal{E}$ Pipe $W o r k s,{ }^{93}$ held that refusal to furnish the individual ratings

90. See Westinghouse Elec. Corp., 113 N.L.R.B. 954 (1955), 54 MICH. L. REv. 865 (1956), where a majority of the NLRB indicated that all a union must show to obtain access to the company's plant for a job evaluation is that the information sought is relevant to an issue under discussion. Two members of the Board were of the opinion that an employer need not allow a union access to his property unless the denial of access "unreasonably impeded" the union in the exercise of its statutory rights. Since one of the majority members considered the information sought irrelevant under the particular facts there involved, the company was not required to grant access in this case. ion).

91. See Whitin Mach. Works, 108 N.L.R.B. 1537, 1541 (1954) (concurring opin-

92. See Taylor Forge \& Pipe Works, 113 N.L.R.B. 693, 696 \& n.9 (1955).

93. 113 N.L.R.B. 693 (1955). Chairman Farmer and Member Leedom dissented, contending that the employer need not disclose his subjective judgment as to, e.g., the degree of physical effort involved in a job. Rather, such matters are to be determined at the bargaining conference. The Seventh Circuit affirmed the Board's decision, one judge dissenting. The opinions followed substantially the same rationale as the majority and dissenting opinions of the Board. Taylor Forge \& Pipe Works v. NLRB, 234 F.2d 227 (7th Cir. 1956). 
is an unfair labor practice, analogizing the information to wage data which is "presumptively relevant."

Although the individual evaluations are clearly relevant to the question of wages, and knowledge thereof would facilitate union appraisal of the company's offer, disclosure of such information could seriously handicap the employer's bargaining position. By accepting for each job management's evaluations of those factors which the union would rate at the same degree or lower, the union could place management in a position where it would be bargaining only on the factors which the union contends should be rated higher and not at all on those which the union might concede should be lower. Although theoretically the employer need not agree to his own prior evaluations, his bargaining position is extremely weak if he seeks to downgrade his own evaluations during negotiations. In addition, although job evaluations are done by an "expert," it is essentially a subjective determination which is just as likely to result in excessive points for some factors as in insufficient points for others, so that it may be more appropriate for the parties to confine their bargaining to the totals, disregarding individual factors. The union can and undoubtedly does make its own evaluations; ${ }^{94}$ as long as the union has enough information for this purpose, it would seem sufficiently informed to bargain intelligently. Therefore, it is submitted that in a case like Taylor Forge a better result would be to deny the union access to management's individual evaluations. This solution would avoid the inequity of diminishing management's bargaining position where the union's need for the data could be satisfied from another source. At the same time, if the parties prefer to bargain on the basis of the individual factor evaluations, they can do so without injury to either side by exchanging their own studies.

\section{WatVER OF Right to INFORMation}

A union is under no obligation to assert all its rights under the NLRA; it may waive its right to strike, ${ }^{95}$ to bargain on a particular question ${ }^{8 B}$ or to be present at the adjustment of grievances. ${ }^{97}$ As long as the waiver is voluntary it will be enforced. ${ }^{98}$ As a result, it has become a common practice for employers to bargain for "management function" clauses empowering the company to act unilaterally in certain areas.9 ${ }^{99}$ Securing such a waiver is one method by which an employer may protect himself from having to disclose information which he considers confidential.

Because a union can bargain away its rights, however, does not mean that in all cases an employer may insist upon the waiver as a condition

94. See id. at 229-30.

95. Shell Oil Co., 77 N.L.R.B. 1306 (1948).

96. Hughes Tool Co., 100 N.L.R.B. 208 (1952) (the contract gave the company exclusive responsibility for decisions concerning the right to subcontract or to have work done by independent contractors).

97. Bethlehem Steel Co., 89 N.L.R.B. 341 (1950).

98. See Hughes Tool Co., 100 N.L.R.B. 208 (1952).

99. See Daykin, supra note 66. 
to signing a contract. For instance, although an employer may with impunity insist that the union waive its right to strike, ${ }^{100}$ his insistence that the union waive its right to be present at the settlement of grievances has been held a refusal to bargain in good faith. ${ }^{101}$ Allowing an employer to insist on waiver of the right to strike has been justified as serving the statutory purpose of avoiding industrial strife. ${ }^{102}$ Nevertheless, the Board's general approach seems aimed at limiting an employer's ability to control the union by demanding a waiver of other rights. ${ }^{103}$

Since the union needs information to bargain intelligently, the employer's duty to furnish it is in substance an integral part of his duty to bargain. Therefore, management's insistence that the union waive its right to information is tantamount to demanding power to decide unilaterally the questions to which the information relates. Accordingly, in New Britain Mach. Co. ${ }^{104}$ the NLRB observed that adamant insistence on such a waiver would constitute a refusal to bargain. Nevertheless, since the union is the best judge of its bargaining needs, there is no reason to expect that a voluntary waiver would not be enforced.

In several cases employers have defended their refusal to provide requested information on the ground that the union had waived its right to it. In no case, however, was there a waiver expressed in the contract. The employer has generally asserted that union acquiescence in management's rejection of a contractual provision requiring disclosure constituted an implied waiver. ${ }^{105}$ At times, management has sought to bolster this claim by invoking a contract clause stating that the writing constituted the entire agreement between the parties. ${ }^{106}$ The NLRB has usually rejected this argument, requiring waiver of such a right to be "clear and unequivocal." 107

Silence is probably an unreliable basis for inferring waiver because a union ordinarily will be unwilling to waive its right to information. In fact, the union's unwillingness to surrender this right may be the reason for the absence of a specific provision on disclosure in the contract. ${ }^{108}$ But in a recent case the Board adopted an expressio unius approach, holding

100. Shell Oil Co., 77 N.L.R.B. 1306 (1948).

101. Bethlehem Steel Co., 89 N.L.R.B. 341 (1950).

102. Ibid.

103. See id. at 345.

104. 105 N.L.R.B. 646 (1953), enforcennent granted, 210 F.2d 61 (2d Cir. 1954).

105. F. W. Woolworth Co., 109 N.L.R.B. 196 (1954), enforcement denied, 235 F.2d 319 (9th Cir. 1956); Item Co., 108 N.L.R.B. 1634 (1954), enforcement granted, 220 F.2d 956 (5th Cir. 1955), cert. denied, 25 U.S.L. WEEK 3153 (U.S. Nov. 19, 1956) (No. 450); New Britain Mach. Co., 105 N.L.R.B. 646 (1953), enforcement granted, 210 F.2d 61 (2d Cir. 1954).

106. California Portland Cement Co., 101 N.L.R.B. 1436 (1952) ; Leland-Gifford Co., 95 N.L.R.B. 1306 (1951), enforcement grauted on order to furnish information but rev'd our other grounds, 200 F.2d 620 (1st Cir. 1952); cf. E. W. Scripps Co., 94 N.L.R.B. 227 (1951).

107. See cases cited in notes 105 and 106 supra.

108. In Hearst Corp., 36 L.R.R.M. 1454 (1955), a union representative testified that the union had abandoned its original proposal for a provision in the contract specifying the information that should be furnished because it believed that it was entitled to the information anyway. Id. at 1455 . 
that by contracting for the employer's divulgence of some information the union had waived its right to any data not so specified. ${ }^{109}$ It would seem better not to recognize this type of implied waiver. Considering the importance of intelligent bargaining as an aid to the rational settlement of labor-management disputes, waiver should not be inferred from conduct which is even slightly ambiguous.

\section{EFfect of the Execution of a Contract}

An employer's failure to furnish requested information may not, and in fact usually does not, result in discontinuance of the negotiations. ${ }^{110}$ Economic necessity may compel the parties to continue bargaining in an effort to reach agreement. Sometimes, even after concluding an agreement without the benefit of the requested data, unions have pressed the employer's refusal as an unfair labor practice and sought disclosure of the information. ${ }^{111}$ Management's contention in such cases that the agreement shows the information was not needed to bargain has been rejected as based on hindsight and not indicative of the true relevance of the data, since there is no way of knowing what the contract would have been had the information been supplied. ${ }^{112}$ "The most that can be inferred from the Union's action is that the advantages of a contract in hand outweigh those which the Union might later obtain when all relevant information would be available to it." 113 For this reason it would appear appropriate to disregard the later agreement in determining whether management's refusal was an unfair labor practice. ${ }^{114}$

An unfair labor practice once found, the employer may assert that subsequent conclusion of the contract has relieved him of his obligation to comply with the union request because the information is no longer relevant.115 Accepting this view, the NLRB has not required management to furnish any data where agreement has eliminated the need for it.110 The finding of an unfair labor practice, with the concomitant posting of notices, is apparently considered sanction enough. However, there is a broad exception to this rule where wage data is involved. Since such informa-

109. Hearst Corp., supra note 108.

110. The union could probably discontinue the negotiations pending a decision by the Board on whether the information has to be furnished without being guilty of a refusal to bargain, $c f$. Times Publishing Co., 72 N.L.R.B. 676, 682-83 (1947), but ordinarily this would not be feasible in view of the delay that would be involved.

111. E.g., Boston Herald-Traveler Corp., 110 N.L.R.B. 2097 (1954), enforcement granted, 223 F.2d 58 (1st Cir. 1955).

112. Ibid.

113. NLRB v. Yawman \& Erbe Mfg. Co., 187 F.2d 947, 949 (2d Cir. 1951).

114. The Board's rule is that conclusion of a collective bargaining agreement does not render moot the allegation of a refusal to bargain. Southern Saddlery Corp., 90 N.L.R.B. 1205,1208 (1950); see Post Publishing Co., 102 N.L.R.B. 648 (1953); Hearst Corp., 102 N.L.R.B. 637 (1953).

115. See F. W. Woolworth Co., 109 N.L.R.B. 196, 204 (1954), enforcement denied, 235 F.2d 319 . (9th Cir. 1956).

116. Ibid.; see Douglas Silk Products Co., 107 N.L.R.B. 450 (1953). 
tion is necessary for policing the contract ${ }^{\mathbf{1 1 7}}$ and will be needed for future bargaining, ${ }^{118}$ the Board has held that the employer must furnish this type of data notwithstanding the signing of a contract. ${ }^{119}$

\section{Conclusion}

The lack of a specific statutory provision on disclosure has not inhibited the Board from requiring employers to comply with union requests for information. On the contrary, the indefiniteness of the statute has enabled the Board to develop its own concepts of what the obligation to bargain entails. ${ }^{120}$ To a large extent the subjective "good faith" approach that characterized the early cases is giving way to the evolution of objectively-determined rules for disclosure. The latter development is probably inevitable, not only because the "good faith" requirement provides no standard for determining what information should be furnished but also because it fails to allow for the situation in which disclosure would be harmful to the employer. Moreover, an objective analysis is more consistent with the underlying argument in these cases that the union needs the information if it is to bargain intelligently. It therefore seems desirable to disregard the subjective approach altogether and require disclosure wherever the union's need for the information outweighs the harm which might thereby result to the employer.

\section{C. $S$.}

117. See F. W. Woolworth Co., 109 N.L.R.B. 196 (1954), enforcenent denied, 235 F.2d 319 (9th Cir. 1956).

118. See E. W. Scripps Co., 94 N.L.R.B. 227, 229 (1951).

119. Boston Herald-Traveler Corp, 110 N.L.R.B. 2097 (1954), enforcement granted, 223 F.2d 58 (1st Cir. 1955) ; F. W. Woolworth Co., 109 N.L.R.B. 196 (1954), enforcentent denied, 235 F.2d 319 (9th Cir. 1956); Post Publishing Co., 102 N.L.R.B. 648 (1953); Hearst Corp., 102 N.L.R.B. 637 (1953).

120. It was argued by management as recently as 1955 that Congress, in enacting a definition of collective bargaining in $\S 8(d)$ of the Taft-Hartley Act, had removed from the NLRB any power to formulate or apply its own definition of the term "to bargain collectively" and had overruled those decisions of the courts and the NLRB which had conceived the duty to bargain as more than to "meet ... and confer ..." See Hugh J. Baker \& Co., 112 N.L.R.B. 828 (1955). It is true that some parts of the original House bill would have had such effect. H.R. 3020, 80th Cong., 1st Sess. $\S 2$ (11) (1947); see H.R. REP. No. 245, 80th Cong., 1st Sess. 7, 19-23 (1947). However, as finally enacted $\S 8$ (d) specifically affected only those prior decisions involving failure to agree to a proposal or to make concessions. See S. REP. No. 105, 80th Cong., 1st Sess. 24 (1947); H.R. Conf. Rap. No. 510, 80th Cong., 1st Sess. 34-35 (1947). Although the NLRB observed that this management argument was not "so clearly lacking in merit as to warrant its summary rejection" by the trial examiner on the ground that it ignored the "good faith" requirement, the Board concluded that $\S 8(d)$ was otherwise declaratory of existing law and that it effected no change in the employer's obligation to furnish information. Hugh J. Baker \& Co., supra at 829. 